\title{
Age-Related Differences in Korean Word Recognition Associated with Phonological Rules and Word Frequency: An Event-Related Potential (ERP) Study
}

\author{
Hye Won Kang, Hyun Sub Sim \\ Department of Communication Disorders, Ewha Womans University, Seoul, Korea
}

Correspondence: Hyun Sub Sim, PhD Department of Communication Disorders, Ewha Womans University, 52 Ewhayeodae-gil, Seodamun-gu, Seoul 03760, Korea

Tel: $+82-2-3277-3538$

Fax: +82-2-3277-2122

E-mail:simhs@ewha.ac.kr

Received: January 3, 2021

Revised: February 1, 2021

Accepted: February 12, 2021

This article is based on a part of the first author's Master thesis.

\begin{abstract}
Objectives: The purpose of this study was to investigate age-related differences according to frequency of words and use of phonological rules in the Korean word recognition process between younger and elderly groups through Event-Related Potentials (ERP) analysis. Methods: A total of 35 participants participated in this experiment. They were asked to judge whether the pronunciation of visual words was identical to the corresponding auditory words. Behavioral data and electrophysiological data were collected. Results: Behavioral results revealed that the elderly group showed significantly lower accuracy and longer response time than the younger group. ERP analysis showed that there was no significant difference between the two groups in the 150-300 ms range. However, for the younger group, the N400 component was observed in the 300-500 ms range regardless of word frequency when the phonological rule was not applied and was more apparent under the low word frequency condition. The topographic patterns of the grand average ERP waveforms for the elderly group showed that the N400 component appeared only under high word frequency when the phonological rule was not applied. However, when the phonological rule was applied, the N400 component was observed only under the condition of low word frequency. Conclusion: Differences in the pattern of applying phonological rules associated with word frequency were found between groups. The current study indicates that word frequency and aging may affect the ability to apply phonological rules. The result of age-related differences in ERP analysis reflects a decline in the simultaneous neural processing of phonological and semantic information.
\end{abstract}

Keywords: Aging, Korean word recognition, Phonological rule, Word frequency, P200, N400
노년은 나이가 들어감에 따라 생물학적 기능의 쇠퇴 및 인지 기 능의 저하를 동시에 경험하게 된다(Caplan, $\mathrm{DeDe}$, Waters, Michaud, \& Tripodis, 2011). 정상적인 노화 과정에서도 뇌는 구조적, 기능적으로 변화할 수 있고 이로 인해 감각, 지각, 기억능력 등이 감 퇴될 수 있다. 특히 노화와 관련하여 나타나는 여러 가지 어려움 중 하나인 인지능력 감소는 의사소통 및 언어능력에 지대한 영향을 주는 것으로 보고되고 있다(Ball \& Owsley, 1993; Kramer \& Willis, 2002). 이러한 인지능력 감소에 따른 언어능력 변화를 측정하는
것은 단어 및 문장 등 다양한 수준에서 이루어질 수 있다. 특히, 단 어처리과정 연구는 단어재인 시 발현될 수 있는 다양한 정보 중 초 기 철자와 관련된 음운정보 및 의미정보를 통합하여 살펴볼 수 있 다는 점에서 의의가 있다.

단어재인(word recognition)은 제시된 단어를 보고 의미를 파악 하는 전반적인 인지처리과정을 뜻한다(Cunningham \& Stanovich, 1993). 단어재인 과정 시 시각적으로 제시되는 문자의 모양을 파악 하고 분석하는 단계에서부터 단어의 빈도에 영향을 받는다. 의미적 
상호연결성이 강한 고빈도 단어(high frequency word)를 재인할 때 는 어휘-의미통로가 활성화되어 철자정보 만으로도 신속히 심성어 휘집(mental lexicon)에 저장되어 있는 동일단어와 연결이 이루어 지게 된다. 이는 자소(grapheme)-음소(phoneme)가 일치하는 규칙 단어는 물론 자소-음소가 불일치하는 불규칙 단어까지 재인이 가 능하게 된다. 하지만 의미적 상호연결성이 약한 저빈도 단어(low frequency word)를 재인할 경우, 우선 단어를 표기에 대응되는 소 리로 전환하는 과정을 거친 후 심성어휘집에 접근하게 된다. 따라 서 단어재인 시 고빈도 단어의 경우에는 활성화 수준이 높아 단어 의 규칙성에 상관없이 빠르고 정확하게 재인이 이루어지나, 저빈도 단어의 경우 표기-음운전환(grapheme-phoneme conversion)절차 가 요구되어 심성어휘집에 도달하기까지의 시간 지연이 발생하게 되고, 활성화 수준이 낮아져 정확도 및 반응시간이 감소하게 된다 (Lee, 1996; Lee, Kwon, \& Lee, 2018). 또한 원활한 단어재인을 위해 서는 한글의 특성인 음운규칙(phonological rule: 음절과 음절이 만나 2음절을 구성하는 경우 음이 달라지는 현상을 규칙화 시켜 놓 은 것)을 이해하고 활용하는 능력, 즉 음운지식이 요구된다. 이러한 음운규칙에 관한 지식은 연령이 증가함에 따라 정교화 되어야 하 며 초등학교 고학년 이후에는 습득된 음운인식능력을 통해 실제로 적용할 수 있게 된다(Lim \& Kim, 2008).

그러나 노년기에 들어서면 인지 및 정신적 능력이 아동이 성장하 는 과정의 역순으로 감퇴한다(Raz \& Kennedy, 2009). 또한 노화로 인한 뇌 영역 활성화의 감소는 언어처리 능력에 영향을 미쳐 단어 를 재인하는 과정에 영향을 주게 된다. 신경학적으로 젊은 청년층 의 경우 우반구(right hemisphere) 영역의 두정엽(parietal region) 을 통해 단어재인이 이루어 지지만, 우측 두정엽(right parietal region)의 경우 좌측 두정엽(left parietal region)에 비해 노화에 취약 한 영역으로, 이로 인해 두정엽에 의존하는 과제 역시 노화에 영향 을 받는다(Yoon, 2011). 이러한 신경학적 측면에서의 노화 현상은 단어 판단 여부 및 반응시간과 관련된 수행력 저하로 나타난다 (Lee, Lee, Song, \& Kim, 2014). Burke, MacKay와 James (2000)의 연구에 의하면 노년층은 음운 및 철자와 관련된 회상을 하는데 어 려움을 보인다. 특히 어휘의 개념을 음운과 철자의 형태로 연결할 때 친숙도 및 음운 유사성이 낮은 단어에서 더 큰 어려움을 보인다. 또한 구문 구조의 복잡성 및 인지처리 부담이 요구되는 과제의 경 우, 인지 기능 및 주의력 감소로 인해 노년층의 수행력이 감소된다 (Hutchinson \& Beasley, 1976; Lee \& Sung, 2015). 이렇듯 노화로 인 한 언어능력 수준 저하의 양상은 다면적이고 복잡한 인지처리능력 과 관련되어 있다.

노년층을 대상으로 단어재인 시 음운 및 의미와 관련된 언어처
리능력을 살펴본 선행연구는 이름 대기, 의미 및 범주판단, 음독, 읽 기, 쓰기 등과 같은 과제를 통해 정반응률 및 반응속도를 분석하는 행동측정 방식으로 이루어져 왔다. 이러한 연구방법은 과제를 수 행할 때 호흡, 조음 및 발성 기관, 손 운동 등이 개입되기 때문에 언 어처리과정(language processing)을 온전히 분석하는데 제약이 있 으며, 수행결과만을 제시해주기 때문에 신경학적 처리(neural processing)가 뇌에서 어떻게 일어나는가를 확인하고 해석하기에는 어 려움이 있다. 따라서 본 연구는 단어재인 과정에서 단어빈도 및 음 운규칙 적용 여부에 따라 청년층과 노년층 간 어떠한 차이가 있는 가를 사건관련전위(event-related potential, ERP)를 통해 알아보고 자하였다.

사건관련전위(ERP)는 뇌에서 일어나는 인지과정의 정보처리를 나타내는 것으로 특정 정보가 포함되어 있는 자극이 제시된 이후 해당 자극과 관련하여 일정기간 동안 일어나는 뇌의 전기적 활동 을 의미한다. ERP는 뇌에서 발생하는 신경학적 처리과정을 실시간 반영할 뿐만 아니라 언어처리단계를 반영하는 특정 ERP 성분 파형 들을 보여준다(Kwon, Nam, \& Lee, 2015). ERP 성분 중 P200 성분 은 의미처리 이전에 발현되는 철자 및 음운처리와 관련이 있는 초 기 성분으로, 자극 제시 후 약 $200 \mathrm{~ms}$ 대에 양의(positive) 방향으로 발생하는 진폭(amplitude)을 의미한다. P200 성분은 목표자극과 점화자극 간의 음운적인 유사성이 클수록, 음운적 유사성이 낮은 조건 및 무관련 조건에 비해 성분의 파형이 양의 방향으로 더 크게 나타난다(Kong et al., 2010; Kwon et al., 2015). 예를 들어, Kwon, Lee와 Nam (2011)은 한국어의 무의미 단어를 시각적으로 제시할 때 첫 음절의 음운음절빈도(phonological syllable frequency)와 철 자음절빈도(orthographic syllable frequency) 중 어느 빈도가 P200 에 영향을 미치는가를 조사하였다. 예를 들어, '접합'의 첫 음절 '접' 은 발음상으로는 /저/로 실현된다. 즉, '접합'의 첫 음절은 표기상으 로는 '접'이지만 발음상으로는 /저/인 것이다. 전자를 철자음절, 후 자는 음운음절이라 일컫는데, 무의미 단어 내 각 조건의 첫 음절에 위치하는 빈도를 조절하여 실험을 진행하였다. 연구 결과, 단어의 첫 음절에 나타나는 음운음절빈도가 높을 때 보다 낮을 때에 P200 의 활성화가 크게 나타났다. 반면 철자음절빈도는 P200에 영향을 미치지 않았다. 이러한 연구 결과는 한국어에서 음운적 요인이 철 자적 요인 보다 P200 성분의 활성화에 중요한 기여를 한다는 것을 시사한다.

$\mathrm{N} 400$ 성분은 의미처리와 관련이 있는 성분으로 자극 제시 후 300-500 ms 사이에 관찰되며 음의(negative) 방향으로 발생되는 진 폭을 의미한다. 즉, $\mathrm{N} 400$ 성분은 목표자극과 점화자극이 관련이 없거나 의미적 오류(violation)가 감지될 때 활성화된다(Kutas \& 
Federmeier, 2011). 단어의 빈도와 관련해서는 고빈도 단어보다 저 빈도 단어에서 부적 파형이 관찰된다(Federmeier, Van Petten, Schwartz, \& Kutas, 2003). Van Petten과 Kutas (1990)는 청년층을 대상으로 문장의 처음(the first open-class words), 문장의 중간(intermediate open-class words), 문장의 마지막(sentence-terminal words)에 사용빈도가 서로 다른 단어를 위치시킨 후, 문장 내 단어 위치에 따른 빈도효과를 살펴보았다. 그 결과, 사용빈도가 낮은 단 어에서 부적 성분이 발현되었으며, 문장의 처음에 위치하였을 때 빈도효과가 나타나 위치에 따른 단어빈도 효과 역시 유의한 것으 로 나타났다. 이러한 연구결과는 N400 성분이 의미처리와 관련되 어 나타난다는 것과 동시에 의미적 연결성이 낮은 자극에 반응하 는 성분임을 시사한다. 또한 단어재인 과정에서 빈도가 미치는 효 과는 단어가 포함된 문장 및 문맥을 통해 통합적 관점에서 처리되 는 것임을 시사한다.

또한 N400 성분은 철자(표기) 및 음운정보와 관련되어 나타나 기도 한다(Mcpherson, Ackerman, Holcomb, \& Dykman, 1998; Praamstra \& Stegeman, 1993). Kwon, Choi와 Lee (2016)의 연구는 단어의 청각적 재인 시 단어를 표기가 일치되게 읽은 경우(철자일 치)와음운이 일치되게 읽은 경우(철자불일치)를 통해 표기가 일치 되게 읽은 경우 N400 파형의 부적 진폭을 보고하였다. Meng, Jian, J., Shu, H., Tian과 Zhou (2008)의 연구는 성인 집단에서는 음운불 일치와 철자(Chinese characters)불일치가 N400에 미치는 영향력 에 차이가 없으나, 아동 집단에서는 음운불일치 때 보다 철자불일 치한 상황일 때 $\mathrm{N} 400$ 이 더 활성화가 된다고 보고하였다. 따라서 이 연구는 철자불일치와 음운불일치가 N400 성분에 영향을 미치는 정도가 성인과 아동에 따라 다르다는 것을 시사한다.

최근 한국에서도 $\mathrm{ERP}$ 를 활용하여 음운 및 의미처리와 관련된 연구(Choi \& Sim, 2019; Won \& Sim, 2020)가 실시되었다. Choi와 $\operatorname{Sim}$ (2019)의 연구는 정상 청년층을 대상으로 단어재인 시 의미유 무 및 음운규칙 적용 여부에 따라 처리과정이 다른가를 살펴보았 다. 그 결과, 의미단어에서는 음운규칙이 적용되지 않았을 때(철자 일치)가 음운규칙이 적용되었을 때(철자불일치) 보다 N250 성분이 더 활성화되었고, 무의미 단어에서는 유의미한 차이가 없었다. N250은 하위-어휘처리(sublexical processing) 수준의 자소-음소 대응처리를 반영한다(Grainger \& Holocomb, 2009). 이러한 연구 결과는 자소-음소 전환 처리는 단어의미 유무에 따라 서로 각기 다 른 통로로 활성화됨을 시사한다. Won과 $\operatorname{Sim}$ (2020)의 연구는 단 어재인 시 한국어 원어민 및 이중언어 사용자를 대상으로 음운규 칙 적용 여부에 따른 활성화 정도를 살펴보았다. 그 결과, 음운판단 과제의 행동분석에서는 한국어 원어민 및 이중언어 사용자 사이에
집단 간 유의미한 차이가 나타나지 않았으나, N250 성분에서 두 집 단 간 평균진폭이 유의미한 차이를 보였다. 이러한 연구결과는 이 중언어 사용자가 한국어 원어민 보다 자소-음소를 처리하는 능력 이 제한되어 있음을 보여준다. 또한 P200 성분에서는 집단 및 음운 규칙 적용 여부에 따른 유의한 차이가 나타나지 않았지만 N400 성 분에서는 음운규칙 적용 여부간 차이가 나타났다.

위에서 언급된 선행연구들은 비교집단 없이 단일집단을 통해 연 구가 진행되었거나 주로 청년층을 대상으로 한 연구이다. 또한 한 국에서 실시된 노년층의 언어처리능력에 관한 ERP 연구들(Jo \& Sung, 2018; Yoo \& Sung, 2018)은 문장처리수준에서의 연구가 주 를 이루고 있다. 따라서 본 연구에서는 청년층과 노년층을 대상으 로 단어재인 시 처리과정을 행동분석 및 ERP 분석을 통해 살펴봄 으로써, 단어재인 시 나타나는 단어빈도에 따른 음운규칙 적용 양 상이 노화를 감지할 수 있는 주요한 언어적 지표가 될 수 있는지 알 아보고자 하였다. 이를 위하여 본 연구는 (1) 청년층과 비교하여 노 년층이 음운규칙을 적용하는데 단어의 빈도에 따라 얼마나 어려 움을 보이는가를 정반응률과 반응시간을 측정하여 행동분석을 하였고, (2) 단어의 빈도에 따른 음운규칙 적용 여부의 ERP 특성을 집단간 P200과 N400을 비교하여 살펴보았다.

\section{연구방법}

\section{연구대상}

본 연구에는 청년층 17 명(여성 10 명, 남성 7 명), 노년층 18 명(여성 9명, 남성 9명), 총 35명이 참여하였다. 청년층은 만 20-29세, 노년층 은 만 60-69세로 집단을 구성하였다. 노년층의 연령 기준은 노인복 지법, 국민기초생활보장법, 고령자고용촉진법에서 규정하는 노년 연령의 평균치를 구하여 60 세 이상으로 연령 기준을 선정하였다.

모든 대상자는 공통적으로 (1) 한국어가 모국어이고, (2) 교육년 수가 12 년 이상으로 고등교육을 마친 자로 청년층 및 노년층 간 교 육년수를 유의한 차이가 없도록 일치시켰고, (3) 오른손잡이 및 시 력 또는 교정시력이 정상이며, (4) Christensen, Multhaup, Nordstrom과 Voss (1991)의 건강선별설문지(Health Screening Questionnaire, HSQ)를 실시하여 인지 및 신경학적, 정신적 이상이 없 음을 확인하였고, (5) Kang (2006)의 한국판 간이정신상태검사 (Korean version of Mini-Mental State Examination, K-MMSE)의 결과가 연령, 교육수준에 따라 $16 \%$ ile 이상 정상 범위에 속하는 자 만 본 연구의 대상자로 선정하였다. 또한 (6) 순음청력검사기기(GSI $18)$ 를 이용하여 각 $\mathrm{Hz}(1,000-2,000-4,000-8,000-1,000-500-250)$ 및 $\mathrm{dB}$ (50-35-30-25)를 순차적으로 들려주고 청력에 이상이 없는 
Table 1. Descriptive information on participants

\begin{tabular}{|c|c|c|c|c|c|c|}
\hline \multirow{2}{*}{ Group } & \multicolumn{2}{|c|}{ Gender } & \multicolumn{2}{|c|}{ Age (year) } & \multicolumn{2}{|c|}{ Education (year) } \\
\hline & Male & Female & Mean (SD) & Range & Mean (SD) & Range \\
\hline Younger & 7 & 10 & $22.65(2.89)$ & $20-29$ & $13.94(1.35)$ & $12-16$ \\
\hline Elderly & 9 & 9 & $63.67(2.95)$ & $60-69$ & $13.78(2.26)$ & $12-18$ \\
\hline Total & 16 & 19 & 43.74 (20.99) & $20-69$ & $13.86(1.85)$ & $12-18$ \\
\hline
\end{tabular}

자들만 대상자로 선정하였으며, (7) 노년층의 경우 추가적으로 Kang 과 $\mathrm{Na}$ (2003)의 서울언어학습검사(Seoul Verbal Learning Test, SVLT)를 실시하여 해당 결과가 연령, 교육수준에 따라 정상 범위 (16\%ile) 내 속하는 자에 한 해 본 연구의 대상자로 선정하였다(Kang, Jang, \& Na, 2012). 집단 간 교육년수에 유의한 차이가 있는지 확인 하기 위하여 일원배치분산분석(one-way ANOVA)을 실시한 결과, 두 집단 간 교육년수는 통계적으로 유의미한 차이가 없는 것으로 나타났다 $\left(F_{(1,33)}=.066, p>.05\right)$. 본 연구에 참여한 각 집단 대상자 정 보를 Table 1에 제시하였다.

\section{실험과제}

단어빈도 및 음운규칙 선정

실험에 사용한 단어는 모두 의미단어로 2 음절 명사 단어 100 개 를 선정하였다. 한국어 어휘 중 2음절로 구성된 단어는 가장 높은 빈도로 보고되고 있으며(Lee, 2004) 선행연구(Lee \& Kim, 2003)에 따르면 조사가 결합된 형태나 동사, 형용사, 부사 등의 품사 활용형 은 무의미 단어로 오인될 가능성이 높다고 보고하였다. 또한 한국 어에서 명사 어휘는 2음절이 대다수를 이루고 3음절 이상인 경우 복합어의 빈도가 높아져 본 연구에서는 2 음절로 구성된 명사형 단 어로 한정하였다. 단어는 모두 자소-음소의 호응 관계가 성립되지 않은 불규칙 단어로 선정하였으며 단어의 절반(50개)씩 고빈도 조 건과 저빈도 조건으로 분류되었다. 단어빈도는 국립국어원의 세종 말뭉치(National Institute of Korean Language, 2010)를 사용하여 빈도색인을 기초로 하였으며 Lee 등(2018) 논문의 빈도범위를 참고 하되 노년층 대상자를 고려하여 본 연구에 맞게 설정하였다. 고빈 도 단어(빈도범위: 550-865)의 평균은 621.34, 저빈도 단어(빈도범 위: 25-83)의 평균은 70.2로 통계적으로 유의한 차이가 있었다 $\left(F_{(1,98)}=45.373 p<.01\right)$. 또한 각 빈도 조건 내에서 음운규칙 적용 여 부 간 단어빈도 차이를 통제하였다. 고빈도 단어의 경우 음운규칙 적용 시 단어빈도 평균 625.52 , 음운규칙 미적용 시 단어빈도 평균 629.76 으로 통계적으로 유의미한 차이가 없었으며 $\left(F_{(1,48)}=.005, p>.05\right)$ 저빈도 단어의 경우 역시 음운규칙 적용시 단어빈도 평균 70.16 , 음운 규칙 미적용 시 단어빈도 평균 70.24로 통계적으로 유의미한 차이가 없었다 $\left(F_{(1,48)}=.000, p>.05\right)$. 또한음운규칙의 경우 $\operatorname{Lim}(2006)$, Lee
(1990)의 논문을 참고하여 발생빈도 백분율이 $0.1 \%$ 보다 높은 12 개 의 음운규칙(장모음화, 경음화, 음절말 장애음 중화, 연음화, 단모음 화, 비음화, 두음법칙, 구개음 뒤의 $\mathrm{y}$-탈락, 격음화, 할락, 유음화, ᄂ삽입) 가운데 필수적으로 음운규칙이 적용된 발음이 표준발음 으로 인정되는 음운규칙을 선정하였으며 이는 경음화(6.43\%), 연 음화(3.1\%), 격음화(0.57\%), 유음화(0.35\%), 비음화(0.82\%)에 해당 된다(Lim, 2006). 본 연구에서는 음운규칙 중 해당 5 가지 규칙으로 제한하여 살펴보았다.

\section{음운판단과제}

실험과제는 100 개의 실험 문항, 50 개의 메꿈(filler) 문항으로 실 험 문항은 모두 2 음절 불규칙 의미단어로 구성하였다. 메꿈 문항 또한 규칙 단어와 불규칙 단어들을 사용하여 정상 문항과 오류 문 항의 비율을 동일하게 맞추었다. 본 연구는 음절 수에 따른 수행능 력을 살펴보는 것이 아닌 음운판단 수행력을 판단하는 실험이기 때문에 음절 수에 따른 수행력의 영향을 제거하고 음운변동이 일 어날 수 있는 최소한의 음절인 2음절로 음절 수를 제한하였다. 피 험자는 화면에 제시되는 단어를 음운규칙을 적용하여 읽고 이후 들려오는 청각자극과 비교하여 정오를 판단해야 했다. 피험자에게 제시된 청각자극은 음운규칙(경음화, 연음화, 격음화, 유음화, 비음 화)을 적용하여 읽은 올바른 형태 단어 50 개, 음운규칙을 적용하지 않고 자소-음소를 일치시켜 읽은 오류형태 단어 50개였다. 음운규 칙이 적용되는 단어는 경음화 20개, 연음화 20개, 격음화 20 개, 유 음화 20 개, 비음화 20 개 총 100 개로 각 음운규칙별 절반씩 나누어 10 개의 단어는 시각자극과 청각자극이 일치하게 배분하였으며 나 머지 절반은 시각자극과 청각자극이 불일치하도록 배분하였다. 실 험조건 및 자극의 예는 Table 2에 제시하였으며, 실험에 사용된 자 극단어 목록은 Appendix 1 에 제시하였다.

\section{청각자극 녹음}

실험에 사용된 모든 청각자극은 아나운서 출신 여성이 디지털 녹음기(Sony, ICD-UX560F)로 방음이 되는 조용한 쉴드룸에서 녹 음하였다. 청각적 자극은 디지털 녹음기에 의해 24 비트, $96 \mathrm{kHz}$ 로 디지털 신호로 변환되어 저장되었다. 청각적 자극에 사용된 2음절 
Hye Won Kang, et al. • Age-Related Differences in Phonological Rules and Word Frequency

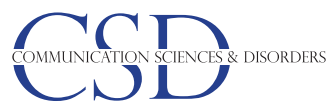

Table 2. Example of stimulus words

\begin{tabular}{|c|c|c|c|}
\hline Phonological rules & Examples of visual stimulus & Type of sound stimulus & Examples of auditory stimulus \\
\hline \multirow[t]{2}{*}{ Tensification } & t6 ${ }^{\mathrm{h}} \Lambda \Gamma^{\top} \mathrm{do}$ (철도) & Inconsistent in spelling & $t \epsilon^{\mathrm{h}} \Lambda \mathrm{l}^{\top} \mathrm{t} \mathrm{o}_{\mathrm{O}}$ (철또) \\
\hline & & Consistent in spelling & tc ${ }^{\mathrm{h}} \Lambda \mathrm{l}^{\top} \mathrm{do}$ (철도) \\
\hline \multirow[t]{2}{*}{ Liason } & mit’um (믿음) & Inconsistent in spelling & midum (미듬) \\
\hline & & Consistent in spelling & mit?um (믿음) \\
\hline \multirow[t]{2}{*}{ Aspiration } & p okheñ (폭행) & Inconsistent in spelling & $\mathrm{p}^{\mathrm{h}} \mathrm{ok}^{\mathrm{h}} \varepsilon \eta \eta^{(ㅍ ㅗ ㅋ ㅐ ㅇ) ~}$ \\
\hline & & Consistent in spelling & $\mathrm{p}^{\mathrm{h}} \mathrm{okh} \varepsilon \hat{y}$ (폭행) \\
\hline \multirow[t]{2}{*}{ Liquidization } & non̄ri (논리) & Inconsistent in spelling & nol’li (놀리) \\
\hline & & Consistent in spelling & non̉ri (논리) \\
\hline \multirow[t]{2}{*}{ Nasalization } & cimrin (심리) & Inconsistent in spelling & cimīni (심니) \\
\hline & & Consistent in spelling & cimīri (심리) \\
\hline
\end{tabular}

단어는 평균 길이가 $952 \mathrm{~ms}$ (범위 851-1,236 ms)였다.

\section{연구절차}

\section{실험 진행 절차}

실험자극은 총 150 개 문항으로 피험자마다 E-Prime 내 무작위 배열(randomization)로 제시되었다. 또한, 실험 전 예제문항을 실시 하여 피험자에게 과제에 대한 이해를 충분히 시켰다. 예제문항은 음운규칙 별 2 개씩 총 10 개의 문항을 무작위로 제시하였으며 피험 자의 과제 수행 방식의 이해를 돕기 위해 각 예제문항 당 피험자의 반응에 대한 피드백이 제공되었다.

본 실험이 시작되면 ‘+’ 표시가 $500 \mathrm{~ms}$ 동안 화면 가운데 나타나 피험자 시선을 고정시키고 곧바로 $500 \mathrm{~ms}$ 동안 빈화면이 제시되었 다. 이후 2 음절 단어의 시각자극이 모니터 중앙에 $800 \mathrm{~ms}$ 동안 나 타났다 사라진 뒤 곧바로 해당 2 음절 단어의 청각자극을 빈 화면 과 함께 최대 5,000 ms 동안 제시하였다. 청각자극 제시 이후, 화면 에 제시된 단어를 스피커로 들려주는 아나운서가 올바르게 읽어 자연스럽다고 판단되면 키보드 오른쪽의 'O' 버튼을, 혹은 올바르 게 읽지 않아 부자연스럽다고 판단되면 키보드 왼쪽의 ' $X$ ' 버튼을 정확하고 신속하게 누르도록 지시하였다. 피험자가 반응하면 500 $\mathrm{ms}$ 의 빈 화면이 나타나고 그 후 눈을 깜박이면서 다음 문항을 준비 하도록 $1,500 \mathrm{~ms}$ 의 시간을 제시하였다. 전체 150 개 문항 실험의 총 소요 시간은 20 분 정도 소요되었고 50 문항마다 약 1 분간 휴식하였 다. 해당 음운판단과제의 자극 제시 절차는 Figure 1 과 같다.

\section{$\mathrm{ERP}$ 실험}

피험자가 음운판단과제를 수행하는 동안 뇌전도(EEG)가 녹화 되었으며 실험자극 외 외부 요인으로 인한 전파를 차단하기 위해 쉴드룸(shield room)안에서 Brain Product사의 BrainAmp Standard와 actiCAP을 이용하여 실험을 진행하였다. 피험자의 두피에

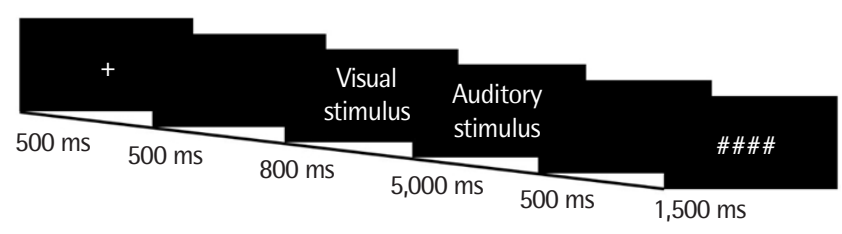

Figure 1. Design of phonology judgment task.

Fp1, Fp2, F7, F3, F4, F8, FC5, FC1, FC2, FC6, T7, C3, Cz, C4, T8, TP9, CP5, CP1, CP2, CP6, TP10, P7, P3, Pz, P4, P8, O1, O2, VEOG 의 총 29 개의 은/염화은 $(\mathrm{Ag} / \mathrm{AgCI})$ 으로 제작된 전극을 국제 표준방 식인 10-20 system (Jasper, 1958)에 따라 부착하였다. 또한 피험자 의 오른쪽 눈 아래 약 $10-15 \mathrm{~mm}$ 위치에 눈 깜박임을 감지하기 위한 전극(electrode)을 부착하고 안전도(electrooculogram, EOG)를 측 정하였으며 기준전극(reference electrode)을 피험자의 양쪽 유양돌 기(mastoids)에 각각 부착하였다. 뇌파 신호는 $500 \mathrm{~Hz}$ 로 샘플링 되 었으며 각 전극의 저항은 $10 \mathrm{~K} \Omega$ 이하로 유지하였다. 분석에 포함된 전극은 Left anterior (Fp1, F3, FC5, FC1, F7), Left posterior (CP5, CP1, P7, P3, O1), Right anterior (Fp2, F4, FC2, FC6, F8), Right posterior $(\mathrm{CP} 2, \mathrm{CP} 6, \mathrm{P} 4, \mathrm{P} 8, \mathrm{O} 2)$ 이다.

\section{자료분석}

음운판단과제 정반응률은 피험자가 화면에 제시된 단어를 스피 커로 들려주는 아나운서의 발음이 자연스러운지 혹은 부자연스러 운지를 판단한 반응을 분석하였다. 단어의 유형별로 정반응한 목 표단어 수를 유형별 전체 목표단어 수로 나누어 백분율(\%)로 계산 하였다.

반응시간은 청각자극이 제시된 순간부터 정오 판단을 위해 버 튼을 누른 시간까지를 E-prime을 통해 측정하였다. 음운판단과제 의 반응시간은 밀리세컨드(millisecond, ms) 단위로 측정하였으며 반응시간은 피험자가 정반응한 문항만 분석하였다. 
피험자가 음운판단과제를 수행하는 동안 얻은 EEG 데이터를 The MathWorks의 MATLAB R2013b내 EEGLAB (v.12.02.0.5b) 프로그램을 통하여 분석하였다. 피험자들이 음운판단과제에서 정 반응한 문항들을 대상으로 $250 \mathrm{~Hz}$ 에 맞추어 다시 샘플링 한 후 청 각자극 제시 전 $200 \mathrm{~ms}$ 을 기저선(baseline)으로 청각자극이 제시 된 후 $800 \mathrm{~ms}$ 까지 총 $1,000 \mathrm{~ms}$ 의 구간(epoch)을 잘랐다. 또한 인지 작용과 관련한 뇌파추출을 위해 $0.1-30 \mathrm{~Hz}$ 범위 내에서 필터링하였 으며, 눈 깜박임 등을 보정하고 기타 잡음(artifacts)들을 제거하였 다. 이러한 과정을 거친 다음 남은 시행들을 조건별로 추출하였다. 이후 조건별 평균을 내고 각 집단 평균 $\mathrm{ERP}$ 파형을 구하였다.

실험에 참여한 35 명(청년 17 명, 노년 18 명)의 자료가 행동 데이터 분석을 위해 사용되었으며 데이터 전처리과정에서 잡음(artifacts) 으로 인해 노년층 2 명이 제외되어 총 33 명(청년층 17 명, 노년층 16 명)의 자료가 ERP 데이터 분석을 위해사용되었다.

본 연구의 첫 번째 연구 문제인 집단(청년층, 노년층) 간 음운규칙 적용 여부(적용, 미적용) 및 단어빈도(고빈도, 저빈도)에 따른 단어 재인 시 정반응률(\%) 및 반응시간(ms)에서 유의한 차이를 보이는 지 알아보기 위하여 삼원혼합분산분석(three-way mixed ANOVA)을 실시하였다. 두 번째 연구 문제인 반구 영역(좌반구, 우반구) 및 전후방 영역(전방, 후방)에서 집단(청년층, 노년층) 간 음운규칙 적용 여부(적용, 미적용) 및 단어빈도(고빈도, 저빈도)에 따른 단어 재인 시 ERP 평균진폭(mean amplitude, $\mu \mathrm{V}$ )에서 유의한 차이가 있는지 알아보기 위하여 오원혼합분산분석(five-way mixed ANOVA)을 실시하였다.

통계적 분석은 SPSS ver.25 (SPSS Inc., Chicago, IL, USA)를 사용 하였다.

\section{연구결과}

\section{정반응률}

음운규칙 적용 여부 및 단어빈도에 따른 음운판단과제의 집단 간 정반응률의 차이를 알아보기 위해 집단, 음운규칙 적용 여부, 단어빈도를 독립변인, 음운판단과제의 정반응률을 종속변인으로 하는 삼원혼합분산분석(three-way mixed ANOVA)를 실시하였
다. 음운규칙 적용 여부 및 단어빈도에 따른 집단별 정반응률(\%)의 평균, 표준편차는 Table 3에 제시하였고, Figure 2에는 평균 및 표준 오차를 제시하였다.

음운규칙 적용 여부 및 단어빈도에 따른 음운판단과제의 집단 간 정반응률에서 집단에 대한 주효과가 통계적으로 유의하였다 $\left(F_{(1,33)}=32.994, p<.001\right)$. 즉, 청년층의 평균 정반응률이 노년층의 평균 정반응률에 비해 유의하게 높은 것으로 나타났다. 빈도에 대 한 주효과도 통계적으로 유의하였다 $\left(F_{(1,33)}=32.004, p<.001\right)$. 즉, 고빈도에서의 평균 정반응률이 저빈도에서의 평균 정반응률에 비 해 유의하게 높은 것으로 나타났다. 또한 음운규칙 적용 여부에 대 한 주효과 역시 통계적으로 유의하였다 $\left(F_{(1,33)}=54.164, p<.001\right)$. 즉, 음운규칙이 적용된 조건에서의 정반응률이 음운규칙이 적용 되지 않은 조건에서의 정반응률에 비해 유의하게 높은 것으로 나 타났다.

빈도와 음운규칙 적용 여부 간 이차상호작용은 통계적으로 유의 하지 않았다 $\left(F_{(1,33)}=3.275, p>.05\right)$. 그러나 빈도와 집단 간의 이차상 호작용이 통계적으로 유의하였다 $\left(F_{(1,33)}=6.835, p<.05\right)$. 노년층에 서의 빈도 간 정반응률의 차이가 청년층에서의 빈도 간 정반응률 의 차이보다 유의하게 큰 것으로 나타났다. 즉, 청년층과 비교하여 노년층의 경우 고빈도에 비해 저빈도에서 더 큰 수행력 지체를 보였 다. 또한 음운규칙 적용 여부와 집단 간 이차상호작용 역시 통계적 으로 유의한 것으로 나타났다 $\left(F_{(1,33)}=10.282, p<.01\right)$. 노년층에서 의 음운규칙 적용 여부 간 정반응률의 차이가 청년층에서의 음운

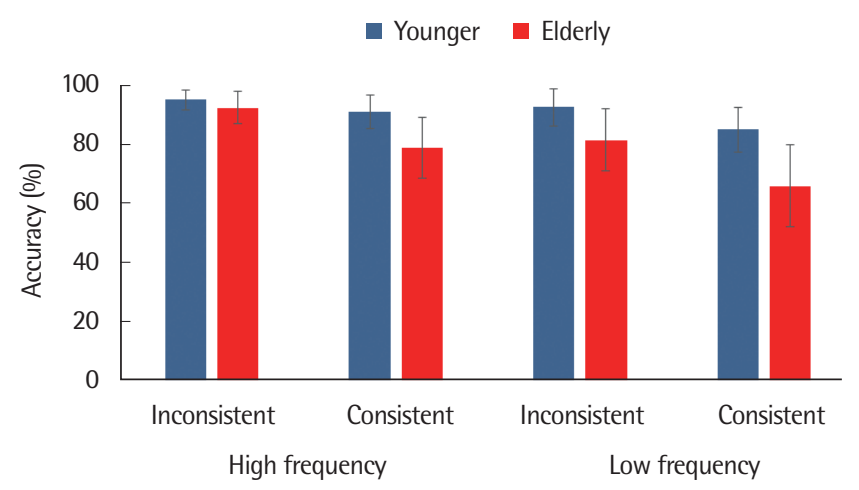

Figure 2. Accuracy on the phoneme judgement task for each condition of younger and elderly groups (error bar based on standard error).

Table 3. Descriptive statistics of accuracy (\%) on the phoneme judgement task for each condition of younger and elderly groups

\begin{tabular}{lccc}
\hline Word frequency & Consistency & Younger (N=17) & Elderly (N=18) \\
\hline High frequency & Inconsistent in spelling & $95.06(3.32)$ & $92.39(5.54)$ \\
Low frequency & Consistent in spelling & $91.06(5.75)$ & $78.67(10.21)$ \\
& Inconsistent in spelling & $92.47(6.18)$ & $81.50(10.49)$ \\
\hline
\end{tabular}


규칙 적용 여부 간 정반응률의 차이보다 유의하게 큰 것으로 나타 났다. 즉, 청년층과 비교하여 노년층의 경우 음운규칙이 적용된 경 우에 비해 음운규칙이 적용되지 않은 경우에서 더 낮은 정반응률 을 보였다. 빈도, 음운규칙 적용 여부, 집단 간 삼차상호작용은 통계 적으로 유의미하지 않은 것으로 나타났다 $\left(F_{(1,33)}=0.3, p>.05\right)$. 삼원 혼합분산분석(three-way mixed ANOVA) 결과는 Table 4 에 제시 하였다.

\section{반응시간}

음운규칙 적용 여부 및 단어빈도에 따른 음운판단과제의 집단 간 반응시간의 차이를 알아보기 위하여 집단, 음운규칙 적용 여부, 단어빈도를 독립변인, 음운판단과제의 반응시간을 종속변인으로 하는 삼원혼합분산분석(three-way mixed ANOVA)를 실시하였 다. 음운규칙 적용 여부 및 단어빈도에 따른 집단별 반응시간(ms) 의 평균, 표준편차는 Table 5에 제시하였고, Figure 3 에는 평균 및 표준오차를 제시하였다.

음운규칙 적용 여부 및 단어빈도에 따른 음운판단과제의 집단 간 반응시간에서 집단에 대한주효과가 통계적으로 유의하였다 $\left(F_{(1,33)}=\right.$ $44.210, p<.001)$. 즉 청년층의 평균 반응시간이 노년층의 평균 반응 시간에 비해 유의하게 빠른 것으로 나타났다. 빈도에 대한 주효과
도 통계적으로 유의하였다 $\left(F_{(1,33)}=207.021, p<.001\right)$. 고빈도에서의 평균 반응시간이 저빈도에서의 평균 반응시간에 비해 유의하게 빠 른 것으로 나타났다. 또한 음운규칙 적용 여부에 대한 주효과 역시 통계적으로 유의하였다 $\left(F_{(1,33)}=115.156, p<.001\right)$. 즉 음운규칙이 적용된 조건에서의 반응시간이 음운규칙이 적용되지 않은 조건에 서의 반응시간에 비해 유의하게 빠른 것으로 나타났다.

빈도와 음운규칙 적용 여부 간 이차상호작용은 통계적으로 유

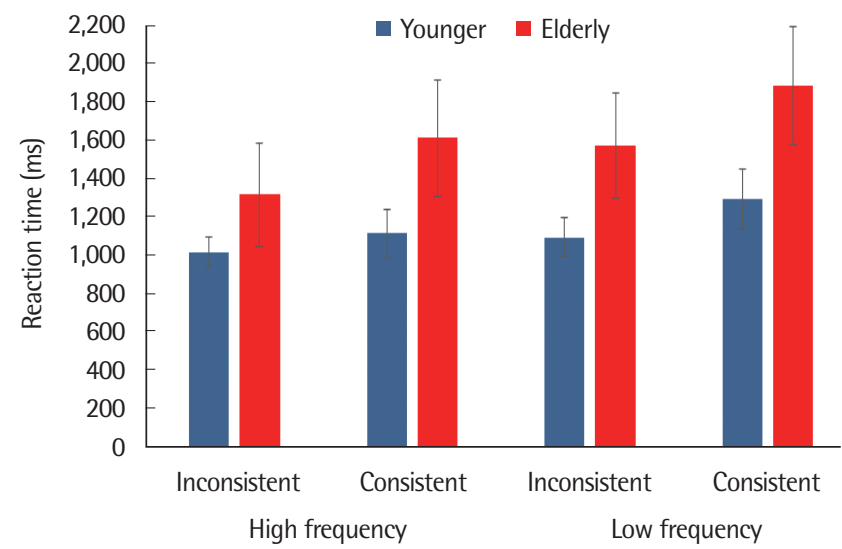

Figure 3. Reaction time on the phoneme judgement task for each condition of younger and elderly groups (error bar based on standard error).

Table 4. ANOVA results from the accuracy (\%) on the phoneme judgement task

\begin{tabular}{|c|c|c|c|c|}
\hline Distributed source & Sum of squares & Degree of freedom & Mean square & $F$ \\
\hline \multicolumn{5}{|l|}{ Between factor } \\
\hline Group & $4,442.80$ & 1 & $4,442.80$ & $32.994^{* * *}$ \\
\hline Error & $4,443.67$ & 33 & 134.657 & \\
\hline \multicolumn{5}{|l|}{ Within factor } \\
\hline Frequency & 2,290.59 & 1 & $2,290.59$ & $32.004^{* * *}$ \\
\hline Frequency $\times$ Group & 489.218 & 1 & 489.218 & $6.835^{*}$ \\
\hline Error & $2,361.88$ & 33 & 71.572 & \\
\hline Consistency & $3,649.63$ & 1 & $3,649.63$ & $54.164^{* * *}$ \\
\hline Consistency $\times$ Group & 692.827 & 1 & 692.827 & $10.282^{* *}$ \\
\hline Error & $2,223.56$ & 33 & 67.381 & \\
\hline Frequency $\times$ Consistency & 64.168 & 1 & 64.168 & 3.275 \\
\hline Frequency $\times$ Consistency $\times$ Group & 5.882 & 1 & 5.882 & 0.3 \\
\hline Error & 646.503 & 33 & 19.591 & \\
\hline
\end{tabular}

${ }^{*} p<.05,{ }^{* *} p<.01,{ }^{* * *} p<.001$.

Table 5. Descriptive statistics of reaction time $(\mathrm{ms})$ on the phoneme judgement task for each condition of younger and elderly groups

\begin{tabular}{lccc}
\hline Word frequency & Consistency & Younger (N=17) & Elderly (N=18) \\
\hline High frequency & Inconsistent in spelling & $1,016.30(75.22)$ & $1,315.57(270.58)$ \\
Low frequency & Consistent in spelling & $1,111.09(128.39)$ & $1,611.49(303.67)$ \\
& Inconsistent in spelling & $1,092.89(100.56)$ & $1,570.76(274.81)$ \\
\hline
\end{tabular}


의하지 않았다 $\left(F_{(1,33)}=4.103, p>.05\right)$. 그러나 빈도와 집단 간의 이 차상호작용이 통계적으로 유의하였다 $\left(F_{(1,33)}=24.586, p<.001\right)$. 노 년층에서의 빈도 간 반응시간의 차이가 청년층에서의 빈도 간 반 응시간의 차이보다 유의하게 큰 것으로 나타났다. 즉 청년층과 비 교하여 노년층의 경우 고빈도에 비해 저빈도에서 반응시간이 더 느 렸다. 음운규칙 적용 여부와 집단 간 이차상호작용 역시 통계적으 로 유의한 것으로 나타났다 $\left(F_{(1,33)}=14.074, p<.01\right)$. 노년층에서의 음운규칙 적용 여부 간 반응시간의 차이가 청년층에서의 음운규 칙 적용 여부 간 반응시간의 차이보다 유의하게 큰 것으로 나타났 다. 즉 유의한 이차상호작용은 청년층과 비교하여 노년층의 경우 음운규칙이 적용된 경우에 비해 음운규칙이 적용되지 않은 경우 에서 더 긴 반응시간을 보인 것에 기인하는 것으로 해석된다. 빈도, 음운규칙 적용 여부, 집단 간 삼차상호작용은 통계적으로 유의미 하지 않은 것으로 나타났다 $\left(F_{(1,33)}=2.594, p>.05\right)$. 삼원혼합분산분 석(three-way mixed ANOVA) 결과는 Table 6에 제시하였다.

\section{평균진폭(mean amplitude, $\mu \mathrm{V}$ ) 크기 분석}

음운규칙 적용 여부 및 단어빈도에 따른 ERP 분석의 집단 간 전 체 평균 파형(grand average wave forms)에 대한 결과는 Figure 4 (청년층), Figure 5 (노년층)에 제시하였다. 집단 모두 P200의 진폭 은 약 $200 \mathrm{~ms}$ 에서 나타났으며 $\mathrm{N} 400$ 의 진폭 시작점은 약 $300 \mathrm{~ms}$ 에 서 나타났다. 유의한 주효과와 상호작용은 분석 구간별로 나누어 통계적 효과가 의미하는 바를 보다 상세하게 기술하였다.

P200 (150-300 ms)

반구 영역 및 전후방 영역에서의 음운규칙 적용 여부 및 단어빈
도에 따른 집단 간 자극 제시 후 150-300 ms 구간 평균 진폭에서 집 단, 음운규칙 적용 여부 및 빈도에 대한 주효과가 통계적으로 유의 하지 않았다. 반구 영역에 대한 주효과가 통계적으로 유의하였다 $\left(F_{(1,31)}=6.285, p<.05\right)$. 즉, 자극 제시 후 $150-300 \mathrm{~ms}$ 구간에서 우반 구의 평균 진폭 $(.279 \mu \mathrm{V})$ 이 좌반구의 평균 진폭 $(-219 \mu \mathrm{V})$ 에 비해 유 의하게 큰 것으로 나타났다. 전후방 영역에 대한 주효과 역시 통계 적으로 유의하였다 $\left(F_{(1,31)}=28.992, p<.001\right)$. 전방 영역의 평균 진폭 $(.89 \mu \mathrm{V})$ 이 후방 영역 평균 진폭 $(-82 \mu \mathrm{V})$ 에 비해 유의하게 큰 것으로 나타났다.

반구 영역 및 전후방 영역에 대한 이차상호작용이 통계적으로 유의하였다 $\left(F_{(1,31)}=10.874, p<.01\right)$. 즉, 우반구에서 전후방 영역 간 평균 진폭의 차이가 좌반구에서 전후방 영역 간 평균 진폭의 크기 차이보다 유의하게 큰 것으로 나타났다. 그 외 상호작용은 유의하 지 않았다.

\section{N400 (300-500 ms)}

반구 영역 및 전후방 영역에서의 음운규칙 적용 여부 및 단어빈 도에 따른 집단 간 자극 제시 후 300-500 ms 구간 평균 진폭에서 집 단에 대한 주효과가 근사적으로 유의(marginally significant)하였 다 $\left(F_{(1,31)}=3.902, p=.052\right)$. 즉, 자극 제시 후 300-500 ms 구간의 청년 층의 평균 진폭(-1.483 $\mu \mathrm{V})$ 이 노년층의 평균 진폭(-.787 $\mu \mathrm{V})$ 에 비해 음의 방향으로 더 크게 나타났다. 그 외 주효과는 유의하지 않았다.

음운규칙 적용 여부 및 집단 간 이차상호작용 역시 근사적으로 유의(marginally significant)하였다 $\left(F_{(1,31)}=3.632, p=.066\right)$. 즉, 노 년층에서 음운규칙 적용 여부에 따른 평균 진폭의 차이가 청년층 에서 음운규칙 적용 여부에 따른 평균 진폭의 차이 보다 더 작은 것

Table 6. ANOVA results from the reaction time (ms) on the phoneme judgement task

\begin{tabular}{|c|c|c|c|c|}
\hline Distributed source & Sum of squares & Degree of freedom & Mean square & $F$ \\
\hline \multicolumn{5}{|l|}{ Between factor } \\
\hline Group & $7,617,646.49$ & 1 & $7,617,646.49$ & $44.210^{* * *}$ \\
\hline Error & $5,686,053.85$ & 33 & $172,304.66$ & \\
\hline \multicolumn{5}{|l|}{ Within factor } \\
\hline Frequency & $1,317,224.01$ & 1 & $1,317,224.01$ & $207.021^{* * *}$ \\
\hline Frequency × Group & $156,434.38$ & 1 & $156,434.38$ & $24.586^{* * *}$ \\
\hline Error & $209,971.43$ & 33 & $6,362.77$ & \\
\hline Consistency & $1,747,528.42$ & 1 & $1,747,528.42$ & $115.156^{* * *}$ \\
\hline Consistency $\times$ Group & $213,580.20$ & 1 & $213,580.20$ & $14.074^{* *}$ \\
\hline Error & $500,786.01$ & 33 & $15,175.33$ & \\
\hline Frequency $\times$ Consistency & $27,788.16$ & 1 & $27,788.16$ & 4.103 \\
\hline Frequency $\times$ Consistency $\times$ Group & $17,567.24$ & 1 & $17,567.24$ & 2.594 \\
\hline Error & $223,515.68$ & 33 & $6,773.20$ & \\
\hline
\end{tabular}

${ }^{*} p<.05,{ }^{* *} p<.01,{ }^{* * *} p<.001$. 

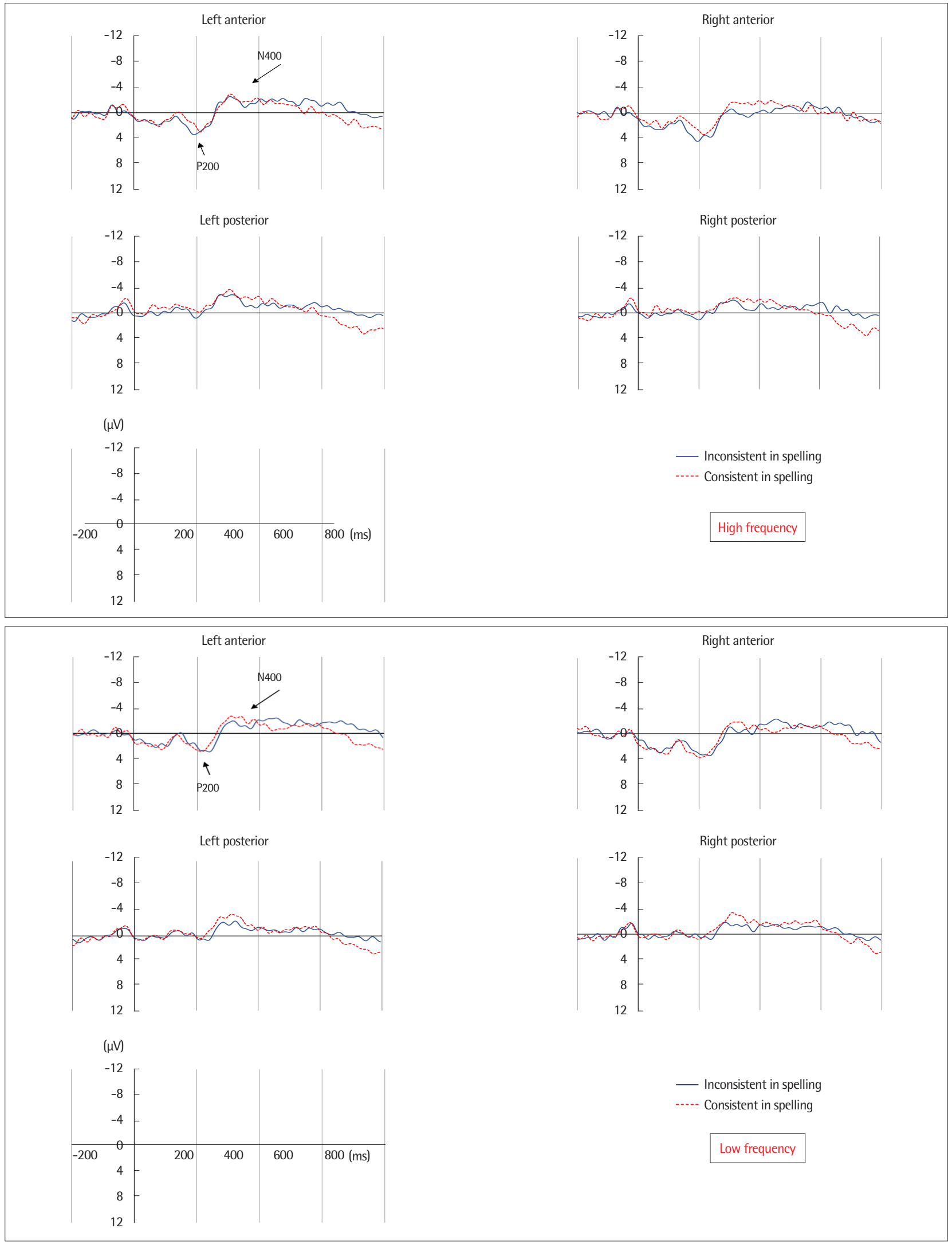

Figure 4. Grand-average event-related potential (ERP) waveforms of four conditions at four regions for younger adults. 

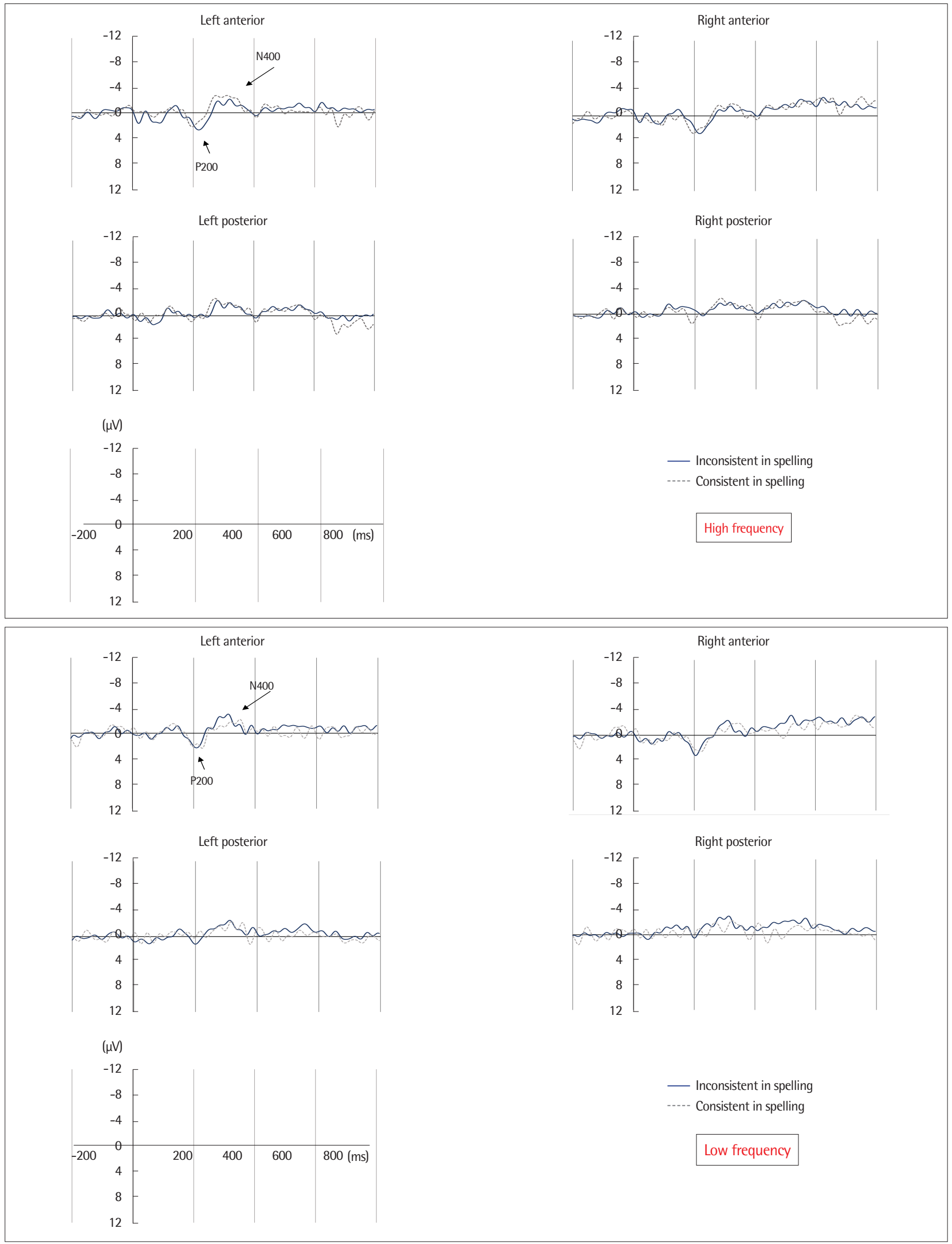

Figure 5. Grand-average event-related potential (ERP) waveforms of four conditions at four regions for elderly adults. 


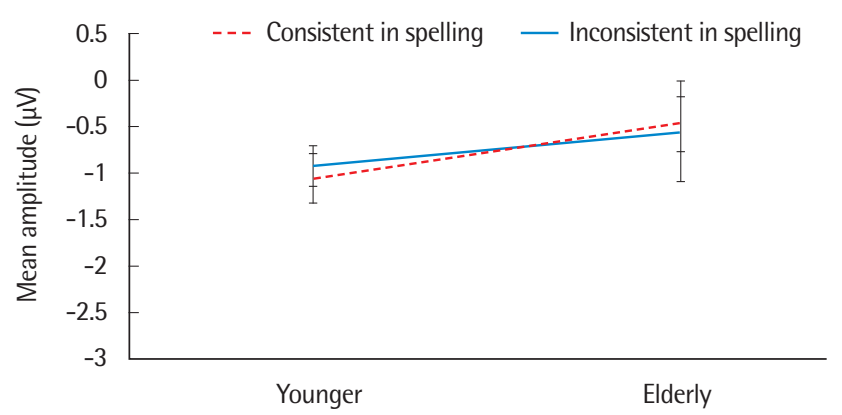

Figure 6. Comparison between consistent in spelling and inconsistent in spelling in younger and elderly groups at left hemisphere.

으로 나타났다. 음운규칙 적용 여부 및 반구 영역, 집단 간 삼차상 호작용이 통계적으로 유의하였다 $\left(F_{(1,31)}=4.244, p<.05\right)$. 즉, 우반 구에서 음운규칙 적용 여부에 따른 집단 간 평균 진폭의 차이가 좌 반구에서 음운규칙 적용 여부에 따른 집단 간 평균 진폭의 차이 보 다 큰 것으로 나타났다. 이에 따라 음운규칙 적용 여부 및 반구 영 역, 집단 간 삼차상호작용에 대해 반구 영역 별로 음운규칙 적용 여 부 및 집단 간 이원분산분석(two-way ANOVA)을 통한 사후검정 을 실시한 결과, 좌반구에서는 음운규칙 적용 여부에 따른 집단 간 차이가 유의하지 않았으나 $(p>.05)$ 우반구에서는 음운규칙 적용 여부에 따른 집단 간 차이가 유의하였다 $\left(\mathrm{F}_{(1,31)}=6.006, p<.05\right)$. 즉, 유의한 삼차상호작용은 우반구, 청년층 집단에서 음운규칙 적용 여부 간 평균 진폭 차이가 노년층에 비해 유의하게 큰 것에 기인한 다. 삼차상호작용 그래프는 반구 별로 Figures 6, 7에 제시하였다. 빈도, 음운규칙 적용 여부, 반구 영역, 전후방 영역, 집단 간 오차상 호작용이 통계적으로 유의하였다 $\left(F_{(1,31)}=10.604, p<.01\right)$. 이에 따 라 집단별로 빈도, 음운규칙 적용 여부, 반구 영역, 전후방 영역 간 사원분산분석(four-way ANOVA)을 통해 사후검정을 실시 한 결 과, 노년층에서는 빈도, 음운규칙 적용 여부, 반구 영역, 전후방 영 역 간 사차상호작용이 통계적으로 유의하지 않았으나 $(p>.05)$ 청년 층에서는 빈도, 음운규칙 적용 여부, 반구 영역, 전후방 영역 간 사 차상호작용이 통계적으로 유의하였다 $\left(F_{(1,16)}=12.750, p<.01\right)$. 이에 따른 사후검정으로 청년층 집단에서 음운규칙 적용 여부에 따른 빈도, 반구 영역, 전후방 영역 간 삼원분산분석(three-way ANO$\mathrm{VA})$ 을 실시하였다. 그 결과, 음운규칙 미적용에서 반구 영역, 전후 방 영역, 빈도 간 삼차상호작용이 유의하였다 $\left(F_{(1,16)}=17.856, p<\right.$ .01). 반구 영역, 전후방 영역, 빈도 간 MMATRIX를 사용하여 사후 검정을 실시한 결과, 고빈도일 때 우반구 전후방 영역의 평균 진폭 차이가 좌반구 전후방 영역의 평균 진폭 차이보다 음의 방향으로 큰 것에 비해 저빈도 일때 우반구 전후방 영역의 평균 진폭 차이가 좌반구 전후방 영역의 평균 진폭 차이보다 유의하게 음의 방향으

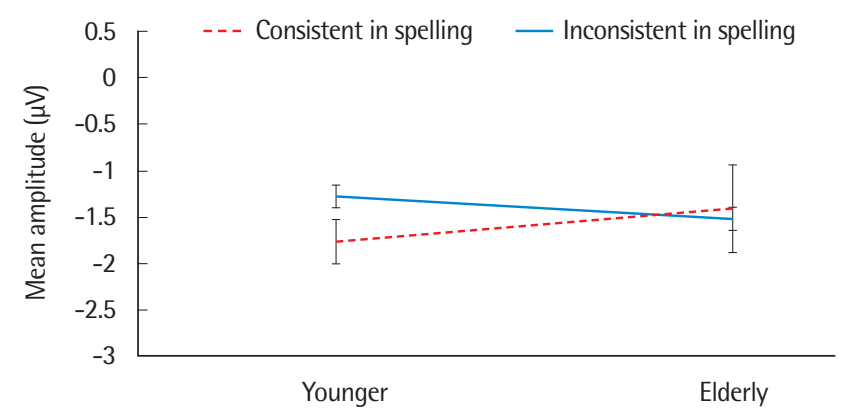

Figure 7. Comparison between consistent in spelling and inconsistent in spelling in younger and elderly groups at right hemisphere.

로 큰 것으로 나타났다. 즉, 유의한 오차상호작용은 노년층 집단에 비해 청년층 집단에서 저빈도 및 음운규칙 미적용일 때, 우반구 전 후방 영역의 평균 진폭 차이가 좌반구 전후방 영역의 평균 진폭 차 이보다 음의 방향으로 유의하게 큰 것에 기인하는 것으로 나타났 다. 그 외 상호작용은 유의하지 않았다.

즉, 집단에 대한 주효과 및 음운규칙 적용 여부 및 집단 간 이차 상호작용이 근사적으로 유의(marginally significant)하였고 음운 규칙 적용 여부, 반구 영역 및 집단 간 삼차상호작용과 빈도, 음운 규칙 적용 여부, 반구 영역, 전후방 영역, 집단 간 오차상호작용이 통계적으로 유의한 것으로 나타났다.

\section{논의 및 결론}

본 연구의 목적은 음운규칙 적용 여부 및 단어빈도에 따른 음운 판단과제에서 집단(청년층 및 노년층) 간 정반응률, 반응시간 및 $\mathrm{ERP}$ 성분의 평균 진폭(mean amplitude) 크기에서 유의한 차이가 있는지 알아보는 것이다. 행동분석 결과, 정반응률, 반응시간 모두 음운규칙 적용 여부, 빈도 및 집단에 대한 주효과가 유의한 것으로 나타났다. 즉, 음운규칙 미적용(철자일치)의 경우 음운규칙 적용 (철자불일치)에 비해 정반응률이 낮아지고 반응시간이 느려지는 것으로 나타났다. 본 연구의 과제는 시각과제를 통한 단어재인 이 후 청각과제를 듣고 음운의 적절성을 판단해야 하는 것으로 두 과 제의 동시적 처리가 요구되었다. 이는 시각단어재인과 청각단어재 인 두 과정을 동시에 활성화시켜 결과를 비교하는 과정에서 나타 난 결과라 할 수 있다. 즉, 시각 및 청각단어재인을 통해 음운 완충 기(phonological buffer)에 도달한 각각의 음운정보가 상응하는 경 우(음운규칙 적용, 철자불일치)에는 판단 속도가 빨라지고 정확도 가 높아진다. 하지만 상이한 경우(음운규칙 미적용, 철자일치)에는 비교하는 과정을 거치기 때문에 시간 지연이 발생했다고 할 수 있 다. 또한, 저빈도 단어는 고빈도 단어에 비해 단어 의미를 인출하는 
데 장기기억(long-term memory)으로부터 더 많은 의미 활성화가 요구되기 때문에 고빈도 단어에 비해 상대적으로 느리게 재인되어 빈도에 따른 효과가 나타났다고 할 수 있다. 집단은 청년층에 비해 노년층이 정반응률 및 반응시간에서 낮은 수행력을 보였다. 특히, 본 연구에서 4 가지 조건 중 저빈도 음운규칙 미적용에서 노년층의 수행력이 급격히 감소되었는데 이는 해당 조건이 언어능력 및 인지 적 기능 저하에 취약할 수 있는 노년층에게 인지적 부담이 가중되 어 나타난 결과라 할 수 있다. 또한, 시각과제에 비해 청각과제를 제 시하였을 때 노년층 집단에서 더 많은 오류 및 긴 반응시간이 발생 하였다고 보고한 선행연구(Cohen, 1979) 결과 와도 동일하다. 이는 시각정보에 비해 청각정보가 사라지는 속도가 빠르고(Colavita, 1974) 노화로 인한 정보처리속도 저하로 인해(Woodruff-Pak, 1997) 제한된 시간 이내 해당 과제를 처리하지 못한 결과로 해석된 다. 따라서 본 연구의 결과 역시 인지적 처리 부담 과중 및 정보처리 속도에 따른 결과가 집단 간차이를 유발하였다고 볼수 있다.

$\mathrm{ERP}$ 성분에 대한 각 시간대 결과를 살펴보면, 자극 제시 후 150 $300 \mathrm{~ms}$ 구간에서 음운규칙 적용 여부 및 빈도, 집단 간 유의한 주 효과 및 상호작용을 확인할 수 없었다. 하지만 파형에 대한 시각적 분석에 의하면, 청년층 및 노년층 전체 평균 파형에서 좌측 전두 (left anterior) 및 우측 전두(right anterior) 영역에서 정적(positive) 파형을 관찰할 수 있었다. 또한, 음운규칙 적용 여부 조건에서 좌전 두 및 우전두 영역 평균파형을 살펴본 결과, 음운규칙 적용(철자불 일치)에서 정적 파형이 더 크게 활성화되었다. 이는 목표자극과 점 화자극 간의 음운적인 유사성이 큰 조건(철자불일치)이 음운적인 관련성이 없는 조건(철자일치)에 비해 정적 방향으로 성분의 파형 이 더 크게 나타난다는 선행연구들(Kong et al., 2010; Kwon et al., 2011)의 결과와 유사한 것으로 볼 수 있다. 하지만 자극 제시 후 150-300 ms 구간에서 표기 및 음운 관련 효과가 통계적으로 유의 하게 나타나지 않은 이유는 방법론적인 차이에서 나타나는 결과라 볼 수 있다. 이러한 본 연구의 결과는 시각단어재인을 통해 P200 성 분이 철자(표기)정보보다 음운정보에 민감하게 반응한다고 보고 한 Kwon 등(2011)의 결과와는 달랐다. 하지만 청각단어재인을 통 해 초기 철자정보를 연구한 선행연구들(Kwon et al., 2016; Won \& $\mathrm{Sim}, 2020)$ 의 결과와는 일치한다. 본 연구의 분석 대상은 청각단어 제시 시점을 기준으로 설정했으며 청각자극이 제시된 이후 과제 정 오 최종 판단 여부가 결정되기 때문에, 본 연구결과의 해석은 시각 단어재인을 통한 처리과정 보다 청각단어를 통한 처리과정에 가깝 다고 볼 수 있다. Golob과 Starr (2004)에 따르면 시각단어재인 혹 은 청각단어재인이 단독적으로 처리되었을 경우 혹은 시각단어재 인과 청각단어재인이 동시에 활성화되었을 경우에는 점화 정도, 출
현 성분 및 경로가 다를 수 있음을 시사한 바 있다. 즉, 단어재인 시 요구되는 방법론적인 차이로 인해 음운규칙 적용 여부와 관련된 철자(표기)-음운 관련 요소가 150-300 ms 구간에 반영되지 않았 을 가능성이 제기된다. 또한 앞서 밝힌 선행연구들과 해당 연구의 결과를 토대로 한국어 언어처리과정에서 P200 성분은 청각 패러 다임(auditory paradigm) 보다 시각 패러다임(visual paradigm)에 서 더 민감하게 반응하는 성분으로 해석할 수 있다.

자극 제시 후 300-500 ms 구간에서 음운규칙 적용 여부, 반구 영 역 및 집단 간차이가 유의하였다. 즉, 이는 노년층이 청년층에 비해 음운규칙 적용 여부에 따른 반구 영역 평균 진폭의 활성화 정도가 약한 것을 의미한다. 이러한 본 연구의 결과는 단어회상 및 작업기 업 과제에서 노화로 인한 뇌 기능 활성화 저하를 보고한 선행연구 들(Cabeza et al., 1997; Nissim et al., 2017)의 결과와 일치하며, 행동 분석에서 음운규칙 적용 여부에 따른 집단 간 수행력 차이를 보여 주는 지표로써 설명될 수있다.

기존의 선행연구들(Davidoff \& Done, 1984; Dundas, Plaut, \& Behrmann, 2013)은 주로 좌반구 (left hemisphere)는 언어처리를 담당하고 우반구(right hemisphere)는 비언어처리를 담당한다고 보고하였다. 하지만 일부 연구들(Chiarello, 1988; Ross, 1981)에서 는 우반구 역시 언어정보처리에 있어 부분적으로 중요한 역할을 담당하고 있다고 보고하였으며, 유의한 삼차상호작용은 우반구에 서 청년층의 음운규칙 적용 여부 진폭의 차이가 노년층에 비해 더 크게 나타난 것에 기인하였는데, 이는 청년층에서 단어재인 시 우 반구 영역의 활성화가 이루어졌음을 짐작해 볼 수 있다.

하지만 다수의 연구들(Crawford, 2015; Szewczyk \& Schriefers, 2018)에서 300-500 ms 구간은 의미가 처리되는 구간으로 밝히고 있기 때문에, 삼차상호작용의 음운규칙 적용 여부는 순수하게 음 운적 요소만이 관여되었을 것이라고 단정 지을 수 없다. 따라서 본 연구의 N400 성분에서 유발되는 음운규칙 적용 여부를 순수하게 음운적인 영향으로만 해석하기에는 무리가 있으며 해당 결과는 단 어재인 과정에서 음운 및 의미처리가 통합적으로 일어난 것으로 해 석된다. 선행연구(Yoo \& Sung, 2018)에서는 통사적 적절성 및 구문 구조와 관련된 동사 구간에서 부적(negative) 전위가 발생하여 $\mathrm{N} 400$ 성분이 관찰되었다. 이러한 현상은 동사구가 제시되기 이전 에 명사구에서 처리된 의미역이 문장의 마지막인 동사구에도 영향 을 미쳐 전체 문장의 의미를 통합하는 과정을 반영한다고 해석하 였다. 즉, 앞서 발생한 의미역 관련 처리가 구문 재수정 처리가 이루 어지는 동사가 제시되면서 전체 문장의 의미를 명확하게 만들면서 통합이 가능해진 것으로 보았다. 이러한 결과는 N400 성분이 의미 관련 처리 후 구문처리가 동시에 일어남으로써 해당 처리과정을 통 
합적으로 바라보는 관점을 반영한다고 할 수 있다(Kutas \& Hillyard, 1980). 본 연구의 과제는 순수하게 의미 판단 여부를 요하는 것이 아닌 단어재인 시 개인의 음운지식을 활용하여 빈도 관련 의 미단어에 적용해야 하는 과제이다. 피험자들은 시각적으로 재인하 여 얻은 의미정보를 청각적으로 재인한 음운정보와 비교하여야 하 는데 이는 의미처리와 음운처리가 복합적으로 이루어져야 하기 때 문에 단편적인 처리과정이 아닌 통합적 처리과정을 요구한다고 볼 수 있다. 따라서, 본 연구에서의 N400 성분은 초기에 철자 및 음운 정보와 관련된 음운지식을 토대로 후기에 발현되는 의미정보가 결 합되어 통합적 처리가 이루어진 것으로 해석할 수 있다. 또한, 빈도, 음운규칙 적용 여부, 반구 영역, 전후방 영역, 집단 간 진폭의 차이 가 유의하였는데 이러한 결과는 청년층이 노년층에 비해 음운규칙 적용 여부 및 단어빈도에 대한 점화 효과를 좀 더 민감하게 받아들 인다는 것을 시사한다. Mashal, Gavrieli와 Kavé (2011)는 청년층의 경우 우측 두정엽(right parietal region) 및 우측 전전두엽(right prefrontal cortex)의 활성화를 통해 단어재인 및 인출을 시도한다 고 보고하였다. 이 선행연구의 결과에 기초해보면, 본 연구에서의 유의한 삼차상호작용은 청년층이 저빈도 단어를 재인할 때 우측 후두(right posterior) 영역이 활성화된 것을 시사한다. 청년층의 경 우 시각, 청각정보가 입력된 후 우반구가 활성화되어 단어재인이 이 루어 졌으나, 노년층의 경우는 노화로 인해 청년층에 비해 활성화 정도가 낮아진 것으로 해석할 수 있다. N400 성분의 경우 의미적 오류(violation)가 감지될 때 혹은 점화자극과 비교하여 음운적 연 관성이 없는 경우 음의(negative) 방향으로 큰 진폭을 보이는 것으 로 알려져 있는 성분이다(Weimer, Clark, \& Freitas, 2019). 청년층 의 경우 저빈도에서 음운규칙 적용 여부 간 차이가 고빈도에서 보 다 크게 나타나 고빈도에 비해 저빈도에서 음운규칙 미적용(철자 일치) 일 때 더 큰 부적(nagative) 진폭이 관찰되었으며, 이는 반구 영역 및 전후방 영역에서 유의한 상호작용으로 나타났다. 이러한 연구결과는 청년층을 대상으로 초기 철자 정보처리과정을 사건관 련전위(ERP) 실험을 통해 살펴본 Kwon 등(2016)의 결과와 동일하 다. 즉, 청년층은 저빈도, 음운규칙 미적용(철자일치)에서 의미적, 음운적 오류를 감지하여 N400 성분의 부적 전위가 관찰되었다. 하 지만 노년층의 경우, $\mathrm{ERP}$ 분석 결과로 얻어진 전체 평균 파형 (grand average waveforms)을 살펴보았을 때, 고빈도의 경우 청년 층과 동일한 양상을 보이지만 저빈도의 경우 음운규칙 적용(철자 불일치)에서 부적 전위가 관찰되었다. 이러한 연구결과는 청년층 과는 다르게 노년층은 저빈도 단어에 음운규칙을 적용하였을 때 의미적, 음운적 오류를 감지했다는 것으로 해석할 수 있다. 즉, 예측 도가 낮고 의미적 상호연결성이 약한 저빈도 단어와 음운지식을 동
시에 활성화시키는 과정에 인지적 부담이 가중되기 때문에 노년층 이 특히 저빈도 조건에서 음운규칙을 적용하는데 어려움을 느낀 것으로 보인다. 이는 청년층, 중년층, 노년층을 대상으로 다양한 조 건(규칙 비단어, 불규칙 비단어, 규칙 단어, 불규칙 단어)에서 음독 과제를 실시한 결과, 불규칙 비단어에서 노년층 수행력 저하를 보 고한 선행연구(Yeon et al., 2017)와 그 맥락을 같이 한다. 하지만 저 빈도에서 음운규칙 미적용(철자일치)의 경우 노년층은 청년층과 는 반대로 부적 전위 활성화가 낮게 나타났다. 이러한 연구결과는 저빈도이고 철자가 일치되는 상황에서 노년층은 의미적 처리를 하 지 않고 단지 자소-음소가 1:1로 대응되는 규칙 단어로 재인되었을 가능성을 시사한다.

전체적으로 행동분석 결과 및 $\mathrm{ERP}$ 실시간 처리과정에 대한 결 과를 요약하면 다음과 같다. 행동분석의 결과 노년층은 청년층에 비해 정확도는 낮았고 반응시간은 느렸다. 정반응만 추출하여 분 석한 실시간 ERP 결과에서는 300-500 ms 구간에서 집단에 대한 주효과가 근사적으로 유의(marginally significant)하였으며 청년 층에 비해 노년층의 ERP 평균 진폭의 활성화가 감소하는 현상이 나타났다. 음운규칙 적용 여부 및 빈도에 대한 효과는 행동분석에 서는 모두 나타났으며, 실시간 ERP 처리과정에서는 집단과 마찬가 지로 상호작용을 통해 나타났다. 의미처리 이전 초기 철자 관련 P200 성분이 청년층 및 노년층 집단에 출현한 것은 두 집단 모두 자 소-음소 처리 즉, 음운규칙에 대한 지식을 형성하고 있었음을 의미 한다. 하지만 습득한 음운지식을 토대로 단어재인을 통한 의미처리 가 이루어져야 하는 300-500 ms 구간에서 음운규칙 적용 여부 및 빈도에 따른 뇌 활성화의 정도에 따라 집단 간 차이를 보인 것은, 노 년층에게 음운과 의미를 동시에 처리해야 하는 것이 어려움으로 작용했을 가능성을 시사한다. 청년층의 경우 모든 빈도 조건에서 음운규칙 적용(철자불일치) 보다 미적용(철자일치)에서 더 큰 부 적 파형이 나타나 $\mathrm{N} 400$ 이 관찰되었고, 특히 저빈도 조건에서 더 크 게 활성화되어 나타났다. 하지만 노년층의 경우 전반적으로 의미점 화가 약화되어 나타났으며, ERP 분석 결과로 얻어진 전체 평균 파 형(grand average waveforms)을 살펴보았을 때, 저빈도 조건에서 음운규칙 적용 시 부적 성분이 출현하였다. 노년층의 이러한 양상 은 저빈도의 의미적 표상과 자소-음소 처리와 관련한 음운적 표상 을 동시에 활성화시키는 것이 인지적 처리 부담으로 작용하여 나타 난 결과라고 해석된다.

본 연구의 제한점 및 후속연구를 위한 제언은 다음과 같다. 첫째, 본 연구는 시각단어와 청각단어를 동시에 재인하여 음운판단을 해야 하는 복잡한 처리과정을 포함하고 있다. 이와 같은 이유로 노 년층이 수행하기에 과제의 난이도가 다소 어려웠다고 할 수 있을 
것이다. 그러므로 노년층의 수행력을 고려한 과제 난이도 조정 및 판단 과정의 단순화가 요구된다. 둘째, 본 연구에서 사용되었던 저 빈도 단어의 경우 빈도색인을 기초로 한 수치에 따라 선정되었으나 본 연구에 참여하였던 연구대상자의 학력수준 및 주관적 선호도 에 따른 개인적 체감 난이도가 상이 했음을 배제할 수 없다. 그러므 로 후속연구에서는 비단어(nonword)를 통해 빈도를 통제하여 진 행할 필요가 있다. 셋째, 실험에 사용된 과제에서는 시각자극 제시 시간이 길었기 때문에, 본 논문에서 분석한 해당 파형이 순수하게 청각자극과 관련된 파형이라고 단정 지을 수 없다. 그러므로 후속 연구에서는 과제 양상(modality)을 통일하여 진행할 필요가 있다. 넷째, 본 연구에 참여한 각 집단 대상자 수는 연령 집단을 대표하기 에 적은 수이므로 보다 많은 집단별 대상자를 통해 살펴볼 필요가 있다.

본 연구는 정상적 노화가 단어재인 시 음운규칙 적용 여부와 빈 도를 조절했을 때 오프라인(off-line) 행동 결과와 온라인(on-line) 뇌파 처리과정에 어떠한 영향을 미치는가를 노년층 집단과 청년층 집단을 비교하여 한국어권에서 처음으로 살펴보았다는 점에서 의 의가 있다. 하지만 앞에서 언급된 본 연구의 한계점을 보완하여 향 후 후속연구에는 한국어에서 나타나는 다양한 특성을 노화와 연 결하여 살펴볼 필요성이 요구된다. 본 연구의 결과는 정상적인 노 화와 치매 및 신경학적 손상과 관련된 병리적 대상군을 변별하는 데 중요한 언어적 지표로서 사용될 수 있으며, 또한 노화 과정에서 발현될 수 있는 언어적 특징과 기준을 설정해가는 데 기초연구 자 료로서 활용할 수 있다.

\section{REFERENCES}

Ball, K., \& Owsley, C. (1993). The useful field of view test: a new technique for evaluating age-related declines in visual function. Journal of the American Optometric Association, 64(1), 71-79.

Burke, D. M., MacKay, D. G., \& James, L. E. (2000). Theoretical approaches to language and aging. In T. Perfect \& E. Maylo (Eds.), Models of cognitive aging (pp. 204-237). Oxford, England: Oxford University Press.

Cabeza, R., Grady, C. L., Nyberg, L., McIntosh, A. R., Tulving, E., Kapur, S., ... \& Craik, F. I. (1997). Age-related differences in neural activity during memory encoding and retrieval: A positron emission tomography study. Journal of Neuroscience, 17(1), 391-400.

Caplan, D., DeDe, G., Waters, G., Michaud, J., \& Tripodis, Y. (2011). Effects of age, speed of processing, and working memory on comprehension of sentences with relative clauses. Psychology and Aging, 26(2), 439-450.
Chiarello, C. (1988). Lateralization of lexical processes in the normal brain: A review of visual half-field research. In $\mathrm{H}$. Whitaker (Ed.), Contemporary reviews in neuropsychology (pp. 36-76). Berlin: Springer-Verlag.

Choi, S. J., \& Sim, H. S. (2019). Grapheme-phoneme conversion in Korean word recognition: evidence from event-related potentials. Communication Sciences \& Disorders, 24(3), 647-655.

Christensen, K. J., Multhaup, K. S., Nordstrom, S. K., \& Voss, K. A. (1991). A new cognitive battery for dementia: Relative severity of deficits in Alzheimer's disease. Developmental Neuropsychology, 7(4), 435-449.

Cohen, G. (1979). Language comprehension in old age. Cognitive Psychology, 11(4), 412-429.

Colavita, F. B. (1974). Human sensory dominance. Perception \& Psychophysics, 16(2), 409-412.

Crawford, J. (2015). Facing the facts: Assessing the role of appearance-behavior incongruities through the modulation of the N400 (Doctoral dissertation), Brandeis University, Massachusetts, USA.

Cunningham, A. E., \& Stanovich, K. E. (1993). Children's literacy environments and early word recognition subskills. Reading and Writing, 5(2), 193-204.

Davidoff, J. B., \& Done, D. J. (1984). A longitudinal study of the development of visual field advantage for letter matching. Neuropsychologia, 22(3), 311318.

Dundas, E. M., Plaut, D. C., \& Behrmann, M. (2013). The joint development of hemispheric lateralization for words and faces. Journal of Experimental Psychology: General, 142(2), 348-358.

Federmeier, K. D., Van Petten, C., Schwartz, T. J., \& Kutas, M. (2003). Sounds, words, sentences: age-related changes across levels of language processing. Psychology and Aging, 18(4), 858-872.

Golob, E. J., \& Starr, A. (2004). Visual encoding differentially affects auditory event-related potentials during working memory retrieval. Psychophysiology, 41(2), 186-192.

Grainger, J., \& Holcomb, P. J. (2009). Watching the word go by: On the timecourse of component processes in visual word recognition. Language and Linguistics Compass, 3(1), 128-156.

Hutchinson, J. M., \& Beasley, D. S. (1976). Speech and language functioning among the aging. In H. J. Oyer \& E. J. Oyer (Eds.), Aging and communication (pp. 155-174). Baltimore, MD: University Park Press.

Jasper, H. H. (1958). The ten-twenty electrode system of the international federation. Electroencephalography and Clinical Neurophysiology, 10, 370375. 
Jo, E. H., \& Sung, J. E. (2018). Age-related differences in ERP components associated with processing homonyms depending on the context type of adnominal and verb phrases. Communication Sciences \& Disorders, 23(2), 360-377.

Kang, Y. (2006). A normative study of the Korean-Mini Mental State Examination (K-MMSE) in the elderly. Korean Journal of Psychology: General, 25(2), 1-12.

Kang, Y., Jang, S. M., \& Na, D. L. (2012). Seoul Neuropsychological Screening Battery (2nd ed.). Seoul: Human Brain Research \& Consulting.

Kang, Y., \& Na, D. L. (2003). Seoul Neuropsychological Screening Battery. Seoul: Human Brain Research \& Consulting Co.

Kong, L., Zhang, J. X., Kang, C., Du, Y., Zhang, B., \& Wang, S. (2010). P200 and phonological processing in Chinese word recognition. Neuroscience Letters, 473(1), 37-41.

Kramer, A. F., \& Willis, S. L. (2002). Enhancing the cognitive vitality of older adults. Current Directions in Psychological Science, 11(5), 173-177.

Kutas, M., \& Federmeier, K. D. (2011). Thirty years and counting: finding meaning in the N400 component of the event-related brain potential (ERP). Annual Review of Psychology, 62, 621-647.

Kutas, M., \& Hillyard, S. A. (1980). Reading senseless sentences: brain potentials reflect semantic incongruity. Science, 207(4427), 203-205.

Kwon, Y., Choi, S., \& Lee, Y. (2016). Early use of orthographic information in spoken word recognition: event-related potential evidence from the Korean language. Psychophysiology, 53(4), 544-552.

Kwon, Y., Lee, Y., \& Nam, K. (2011). The different P200 effects of phonological and orthographic syllable frequency in visual word recognition in Korean. Neuroscience Letters, 501(2), 117-121.

Kwon, Y., Nam, Y., \& Lee, Y. (2015). The effect of the phonological information in the Korean visual word recognition: an event related potential study. The Journal of Linguistic Science, 75, 23-42.

Lee, H. S., \& Kim, J. O. (2003). The effects of ease with phonological rules applicability on phonological processing of Korean words and nonwords. Korean Journal of Experimental Psychology, 15(3), 425-454.

Lee, J. S., \& Sung, J. E. (2015). The effects of noun-phrase type and parallel function on online sentence processing for normal elderly adults. Communication Sciences \& Disorders, 20(2), 222-236.

Lee, K. (1996). Phonological rules in oral reading of Korea. Korean Journal of Cognitive and Biological Psychology, 8(1), 1-23.

Lee, S. J., Lee, S. J., Song, J. Y., \& Kim, H. (2014). Characteristics of language comprehension in normal elderly and the mild cognitive impaired. $\mathrm{De}$ - mentia and Neurocognitive Disorders, 13(3), 51-62.

Lee, S., Kwon, Y., \& Lee, Y. (2018). The difference of word regularity effects based on the degree of the phonological rule application and word frequency. The Journal of Linguistic Science, 86, 259-277.

Lee, S. O. (1990). On the functional load of phonetic/phonological rules: A quantitative survey in modern Korean. Language Research, 26(3), 441-467. Lee, Y. M. (2004). A study of children's vocabulary in the elementary school setting (Master's thesis). Ewha Womans University, Seoul, Korea.

Lim, Y. J., \& Kim, Y. T. (2008). A comparison of the ability of 2nd graders and 5 th graders to apply phonological rules in reading exercises. Korean Journal of Communication \& Disorders, 13(4), 635-653.

Lim, Y. K. (2006). A study on the applicability of phonological rules in Hangul Word recognition (Master's thesis). Ewha Womans University, Seoul, Korea.

Mashal, N., Gavrieli, R., \& Kavé, G. (2011). Age-related changes in the appreciation of novel metaphoric semantic relations. Aging, Neuropsychology, and Cognition, 18(5), 527-543.

McPherson, W. B., Ackerman, P. T., Holcomb, P. J., \& Dykman, R. A. (1998). Event-related brain potentials elicited during phonological processing differentiate subgroups of reading disabled adolescents. Brain and Language, 62(2), 163-185.

Meng, X., Jian, J., Shu, H., Tian, X., \& Zhou, X. (2008). ERP correlates of the development of orthographical and phonological processing during Chinese sentence reading. Brain Research, 1219, 91-102.

National Institute of Korean Language. (2010). Sejong literary language corpus. Seoul: Author.

Nissim, N. R., O’Shea, A. M., Bryant, V., Porges, E. C., Cohen, R., \& Woods, A. J. (2017). Frontal structural neural correlates of working memory performance in older adults. Frontiers in Aging Neuroscience, 8, 328.

Praamstra, P., \& Stegeman, D. F. (1993). Phonological effects on the auditory N400 event-related brain potential. Cognitive Brain Research, 1(2), 73-86.

Raz, N., \& Kennedy, K. M. (2009). A systems approach to age-related change: Neuroanatomical changes, their modifiers, and cognitive correlates. In: W. Jagust \& M. D’Esposito (Eds.), Imaging the aging brain (pp. 43-70). New York: Oxford University Press.

Ross, E. D. (1981). The aprosodias: Functional-anatomic organization of the affective components of language in the right hemisphere. Archives of Neurology, 38(9), 561-569.

Szewczyk, J. M., \& Schriefers, H. (2018). The N400 as an index of lexical preactivation and its implications for prediction in language comprehension. 
Language, Cognition and Neuroscience, 33(6), 665-686.

Van Petten, C., \& Kutas, M. (1990). Interactions between sentence context and word frequency in event-related brainpotentials. Memory \& Cognition, 18(4), 380-393.

Weimer, N. R., Clark, S. L., \& Freitas, A. L. (2019). Distinct neural responses to social and semantic violations: An N400 study. International Journal of Psychophysiology, 137, 72-81.

Won, D. R., \& Sim, H. S. (2020). Phonological activation in Korean word recognition between Korean native speakers and Japanese-Korean and Chinese-Korean bilingual speakers: Evidence from event-related potentials. Communication Sciences \& Disorders, 25(1), 126-141.
Woodruff-Pak, D. S. (1997). The neuropsychology of aging. Blackwell Publishing.

Yeon, E. J., Cho, E. B., Lee, S. J., Kim, S. W., Lee, Y., \& Yoon, J. H. (2017). Characteristics of word reading according to word condition in normal adults. Communication Sciences \& Disorders, 22(4), 730-744.

Yoo, H. M., \& Sung, J. E. (2018). ERP components associated with syntactic ambiguity and word order canonicity in processing sentence with ditransitive verb between young and elderly adults. Communication Sciences \& Disorders, 23(3), 660-682.

Yoon, S. A. (2011). The developmental task and psychological characteristics of the elderly people. Journal of Brain Education, 1, 119-147. 
Appendix 1. Stimuli words

\begin{tabular}{|c|c|c|c|c|}
\hline \multirow{2}{*}{ Phonological rules } & \multicolumn{2}{|c|}{ High frequency } & \multicolumn{2}{|c|}{ Low frequency } \\
\hline & Inconsistent in spelling & Consistent in spelling & Inconsistent in spelling & Consistent in spelling \\
\hline \multirow[t]{5}{*}{ Tensification } & 입술[입쑬] & 용돈 & 일주[일쭈] & 국고 \\
\hline & 갈등[갈뜽] & 철도 & 몰두[몰뚜] & 날조 \\
\hline & 실수[실쑤] & 발생 & 살생[살쌩] & 결사 \\
\hline & 출장[출짱] & 물결 & 결손[결쏜] & 물증 \\
\hline & 말단[말딴] & 갈증 & 혈당[혈땅] & 발산 \\
\hline \multirow[t]{5}{*}{ Liason } & 책임[채김] & 믿음 & 접안[저반] & 안이 \\
\hline & 발음[바름] & 웃음 & 번안[버난] & 날인 \\
\hline & 국어[구거] & 금액 & 심오[시모] & 국익 \\
\hline & 녹음[노금] & 선언 & 반역[바녁] & 선악 \\
\hline & 목욕[모굑] & 답안 & 합일[하빌] & 본업 \\
\hline \multirow[t]{5}{*}{ Aspiration } & 축하[추카] & 폭행 & 각형[가켱] & 혹한 \\
\hline & 식혜[시켸] & 입학 & 박해[바캐] & 약학 \\
\hline & 약화[야콰] & 녹화 & 입헌[이펀] & 잡화 \\
\hline & 국회[구쾨] & 복합 & 곡해[고캐] & 삽화 \\
\hline & 역할[여칼] & 집회 & 약효[야쿄] & 직함 \\
\hline \multirow[t]{5}{*}{ Liquidization } & 설날[설랄] & 탄력 & 안료[알료] & 문란 \\
\hline & 논리[놀리] & 분류 & 신랄[실랄] & 열녀 \\
\hline & 난리[날리] & 반란 & 말년[말련] & 연루 \\
\hline & 건립[걸립] & 인류 & 원론[월론] & 힐난 \\
\hline & 불능[불릉] & 근로 & 안락[알락] & 현리 \\
\hline \multirow[t]{5}{*}{ Nasalization } & 국물[궁물] & 심리 & 강론[강논] & 망락 \\
\hline & 격려[경녀] & 식량 & 낙농[낭농] & 양립 \\
\hline & 성립[성닙] & 독립 & 입론[임논] & 망라 \\
\hline & 집념[짐념] & 확률 & 항로[항노] & 법망 \\
\hline & 섭렵[섬녑] & 창립 & 농락[농낙] & 접목 \\
\hline
\end{tabular}




\section{국문초록}

\section{단어재인 시 음운규칙 적용 여부 및 단어빈도에 따른 청년층 및 노년층의 ERP 성분 비교 분석 강혜원 · 심현섭 \\ 이화여자대학교 일반대학원 언어병리학과}

배경 및 목적: 본 연구는 단어재인 과정에서 단어빈도 및 음운규칙 적용 여부에 따라 나타나는 집단(청년층 및 노년층) 간 연령에 따른 수행력 차이를 사건관련전위(event-related potential, ERP)를 통해 살펴보고자 하였다. 방법: 정상 청년층(17명) 및 노년층(18명) 총 35 명이 참여하였다. 피험자들은 시각단어 제시 이후 연이어 들려오는 청각단어를 비교하여 음운규칙이 올바르게 적용되었는지를 판단 하였다. 과제가 시행되는 동안 정반응률(\%), 반응시간 $(\mathrm{ms})$ 및 뇌파가 측정되었다. 결과: 행동분석 결과, 노년층은 청년층에 비해 유의하 게 낮은 정확도와 긴 반응시간을 보였다. ERP분석 결과, $150-300 \mathrm{~ms}$ 구간에서는 집단 간 유의한 차이가 나타나지 않았다. 하지만, 300$500 \mathrm{~ms}$ 구간에서 청년층의 경우 모든 빈도에서 음운규칙 미적용 시 N400 성분이 관찰되었고 저빈도 조건에서 더욱 뚜렷하게 나타났 다. 반면, ERP 분석 결과로 얻어진 전체 평균 파형(grand average waveforms)을 살펴보았을 때, 노년층의 경우 고빈도 조건에서는 청년 층과 동일하게 음운규칙 미적용 시 N400 성분이 관찰되었으나, 저빈도의 경우 음운규칙 적용 시 N400 성분이 관찰되었다. 논의 및 결 론: 청년층과 노년층이 단어빈도에 따라 음운규칙을 적용하는 양상에 있어 차이를 보였으며, 이러한 차이는 저빈도 단어이고 음운규 칙 미적용 조건에서 두드러지게 나타났다. ERP 분석을 통해 나타난 연령에 따른 차이는 노화로 인해 음운정보와 의미정보를 동시에 처 리하는 능력이 저하된 것이 반영된 것으로 해석된다.

핵심어: 노화, 한국어 단어재인, 음운규칙, 단어빈도, P200, N400

본 논문은 제1저자의 석사학위논문(2020)의 내용을 수정· 보완한 것임.

\section{참고문헌}

강연욱 (2006). K-MMSE (Korean-mini mental state examination)의 노인 규준 연구. 한국심리학회지: 일반, 25(2), 1-12.

강연욱, 나덕렬 (2003). 서울신경심리검사(Seoul Neuropsychological Screening Battery). 서울: 휴브알엔씨.

강연욱, 장승민, 나덕렬 (2012). 서울신경심리검사 2판(SNSB-II). 인천: 휴브알엔씨.

국립국어원 (2010). 세종 현대문어 말뭉치. 서울: 국립국어원.

권유안, 남예은, 이윤형 (2015). 한국어 시각단어 재인 시 음운정보의 영향: 사건관련전위 연구. 언어과학연구, 75, 23-42.

연은주, 조은별, 이수정, 김선우, 이윤경, 윤지혜 (2017). 정상 성인의 단어 조건에 따른 읽기 특성. Communication Sciences \& Disorders, 22(4), 730-

744.

원동란, 심현섭 (2020). 한국어 원어민과 일본어-한국어 및 중국어-한국어 이중언어 사용자 간 음운규칙 적용 여부에 따른 단어재인 시 ERP 성분 비

교. Communication Sciences \& Disorders, 25(1), 126-141.

유혜미, 성지은 (2018). 수여동사구문의 통사적 중의성 및 어순전형성에 따른 노년층 대상 ERP 성분 분석. Communication Sciences \& Disorders,

23(3), 660-682.

윤선아 (2011). 노년기의 발달과제와 심리적 특성. 뇌교육연구 특별호, 1, 119-147.

이광오 (1996). 한글 글자열의 음독과 음운규칙. 한국심리학회지: 인지 및 생물, 8(1), 1-23.

이상억 (1990). 현대국어 음변화 규칙의 기능부담량. 어학연구, 26(3), 441-467.

이선경, 권유안, 이윤형 (2018). 음운규칙 적용도와 단어빈도에 따른 단어 규칙성 효과의 차이. 언어과학연구, 86, 259-277.

이수정, 이승진, 송지연, 김향희 (2014). 정상 노년층과 경도인지장애의 언어 이해력 특성. 대한치매학회지, 13(3), 51-62.

이영미 (2004). 학령기 아동의 학교 상황 어휘 연구: 보완 - 대체 의사소통체계 적용을 위한 기초연구. 이화여자대학교 대학원 석사학위논문. 
이지선, 성지은 (2015). 명사구 속성 일치 여부 및 병행기능 유무가 노년층의 실시간 문장 처리과정에 미치는 영향. Communication Sciences \& Disorders, $20(2), 222-236$.

이해숙, 김정오 (2003). 음운 규칙의 적용 용이성이 음운 정보처리에 미치는 효과. 한국심리학회지: 인지 및 생물, 15(3), 425-454.

임유경 (2006). 한글단어재인에서 음운규칙의 적용도 연구. 이화여자대학교 대학원 석사학위논문.

임유진, 김영태 (2008). 단어 읽기 과제에서 초등 2 학년과 5 학년 아동의 음운규칙 적용능력의 비교. 언어청각장애연구, 13(4), 635-653.

조은하, 성지은 (2018). 관형어 및 동사구 맥락유형에 따라 동음이의어 처리 과정에서 나타나는 청년층 및 노년층 간 ERP 성분 비교. Communication Sciences \& Disorders, 23(2), 360-377.

최서진, 심현섭 (2019). 한국어 불규칙 단어 재인 시 표기-음운변환 처리과정: 사건관련전위 연구. Communication Sciences \& Disorders, 24(3), 647655.

\section{ORCID}

강혜원(제1저자, 대학원생 https://orcid.org/0000-0003-4643-8086); 심현섭(교신저자, 교수 https://orcid.org/0000-0002-4710-3678) 